\title{
Hematoma in the scleral lake: complication of non-penetrating deep sclerectomy
}

\section{Hematomas en el lago escleral: complicación tras esclerectomía profunda no perforante}

\author{
Carmen Navarro-Perea*, Jose L. Torres-Peña and Esperanza Gutierrez-Diaz \\ Ophthalmology Department, Hospital Universitario 12 de Octubre, Universidad Complutense de Madrid, Madrid, Spain
}

\begin{abstract}
Methods: We describe 4 patients suffering from open-angle glaucoma and cataract, and one patient with secondary glaucoma after Fuchs' heterochromic uveitis. All of them underwent phacoemulsification and non-penetrating deep sclerectomy with 5-fluoracil. Two patients presented hematoma in scleral lake $24 \mathrm{~h}$ after surgery, other 2 of them presented it one week after the intervention, and one of them presented it 2 weeks after the surgery. The hematoma was found by gonioscopy in all cases. Moreover, all patients had elevated intraocular pressure. Result: Hematoma usually appears within 2 weeks after surgery. Goniopunctures were performed in 5 patients within 5 months of the complication. A second goniopuncture was needed for one of them. Bleb needling was made in one of them. Three of the patients required treatment with beta-blocker eye drops since intraocular pressure exceeded pre-set values. Conclusion: Hematomas in scleral lake are a rare complication that may appear within 2 weeks after non-penetrating deep sclerectomy. They may cause surgery malfunction and antihypertensive eye drops might be required for tensional control. Goniopuncture could be used for solving the complication.
\end{abstract}

Key words: Glaucoma. Hematoma in the scleral lake. Non-penetrating Deep Sclerectomy. Goniopuncture. Bleb needling.

\section{Resumen}

Método: Presentamos 4 pacientes con glaucoma de ángulo abierto no controlado y cataratas, y un paciente con glaucoma uveítico secundario a heterocromía de Fuchs. Todos ellos fueron intervenidos mediante facoemulsificación y esclerectomía profunda no perforante con 5-fluoracilo. Dos de los pacientes presentaron hematoma en el lago escleral a las $24 \mathrm{~h}$ tras la cirugía, otros 2 a la semana y uno de ellos a las 2 semanas de la intervención. El hematoma se diagnosticó mediante gonioscopia en todos los casos. Además todos presentaron la presión intraocular elevada. Resultado: El hematoma del lago escleral suele aparecer en las 2 primeras semanas tras la cirugía. A todos los pacientes se les realizó goniopuntura en los primeros 5 meses de la complicación y uno de ellos requirió una segunda goniopuntura 3 meses después. A uno de los pacientes se le realizó una cistitomía. Tres de los pacientes requirieron tratamiento con betabloqueantes tópicos para controlar las cifras de presión intraocular. Conclusión: Los hematomas en el lago escleral son una complicación que puede aparecer en las primeras 2 semanas tras una esclerectomía profunda no perforante, pudiendo producir un mal funcionamiento de la cirugía por lo que es necesario la introducción de antihipertensivos oculares para el control de la presión intraocular. La goniopuntura podría ser usada para resolver esta complicación.

Palabras clave: Glaucoma. Hematoma en el lago escleral. Esclerectomía profunda no perforante. Goniopuntura. Cistitomía.

Correspondence:

${ }^{*}$ Carmen Navarro-Perea

E-mail: carmennavarroperea@gmail.com

DOI: 10.24875/RMOE.M19000066
Date of reception: 01-01-2017

Date of acceptance: 12-04-2017
Available online: 08-05-2019 RevMex Oftalmol.(Eng).2019;93(3):125-128

www.rmo.com.mx 2604-1731/@ 2019 Sociedad Mexicana de Oftalmología. Published by Permanyer México SA de CV. This is an Open Access article under the CC BY-NC-ND license (http://creativecommons.org/licenses/by-nc-nd/4.0/). 


\section{Introduction}

Non-penetrating deep sclerectomy (NPDS) is an antiglaucoma filtration surgery technique that has demonstrated to achieve control of intraocular pressure (IOP), with fewer postoperative complications compared to trabeculectomy. The presence of the trabeculo-Descemet's membrane provides a more controlled filtering, thus reducing all potential complications related to anterior chamber leakage (hyphema, hypotonia, choroidal detachments, intraocular inflammation, endophthalmitis, among others) ${ }^{1}$. Within the complications of NPDS, the presence of blood in the scleral lake has been described, which can compromise the success of the procedure; however, there is little literature on this.

We present a retrospective study, evaluated and accepted by the Research Committee. We report 5 cases with this complication. Only two of them achieved satisfactory postoperative IOP control without hypotensive treatment.

\section{Clinical cases}

\section{Clinical case 1}

A 48-year-old male without antiplatelet or anticoagulant therapy, with uveitic glaucoma secondary to Fuchs heterochromia in the right eye, with poor IOP control despite topical treatment, warranting NPDS with 5-fluorouracil and phacoemulsification which was performed without complications. The IOP $24 \mathrm{~h}$ after surgery was $13 \mathrm{mmHg}$, but one week after the intervention, the patient had an IOP of $36 \mathrm{mmHg}$ with flattening of the filtering bleb and a dark red appearance in the temporal zone of the flap. A suspected diagnosis of scleral lake hematoma was made, which was confirmed by gonioscopy. Topical treatment with timolol + brimonidine plus dexamethasone was started. In the following examinations the IOP dropped to $10 \mathrm{mmHg}$ and the hematoma had partially resolved. After one month, hypotensive treatment was withdrawn and the IOP increased again (22 $\mathrm{mmHg}$ ). We performed goniopuncture without achieving a significant decrease in IOP (it remained at $21 \mathrm{mmHg}$ ), requiring reinitiation of topical hypotensive treatment.

\section{Clinical case 2}

A 78-year-old male treated with clopidogrel had a diagnosis of primary open-angle glaucoma (POAG) with elevated IOP despite maximum medical treatment and optic atrophy in the right eye, warranting NPDS with 5-fluoracil and phacoemulsification. Intraocular pressure 24 hours after surgery was $22 \mathrm{mmHg}$, so timolol eye drops were prescribed. Two weeks later, we observed by gonioscopy that the scleral lake was filled with blood, with an IOP of $17 \mathrm{mmHg}$ with treatment. We decided to observe the patient and hypotensive treatment was withdrawn. After 5 months, IOP increased again to $22 \mathrm{mmHg}$ so a goniopuncture was performed followed by a cystotomy, without achieving sufficient IOP reduction. This required hypotensive topical treatment reinitiation to maintain IOP control.

\section{Clinical case 3}

A 70-year-old male treated with acetylsalicylic acid as antiaggregant therapy and treated for POAG with an $80 \%$ optic disc excavation, showed a high IOP (32 $\mathrm{mmHg}$ ) despite topical hypotensive treatment. We decided to perform NPDS with 5-fluorouracil. Intraocular pressure 24 hours after surgery was $6 \mathrm{mmHg}$. Fifteen days later, the patient had an IOP of $37 \mathrm{mmHg}$, with marked conjunctival hyperemia and blood in the scleral lake visible by gonioscopy, so topical treatment with timolol was initiated and topical corticosteroid therapy was maintained. One month after surgery, the bleb was examined and a subconjunctival mitomycin- $C$ injection $(0.002 \mathrm{mg} / \mathrm{mL})$ was applied, without achieving IOP reduction $(30 \mathrm{mmHg})$. Two months after surgery a goniopuncture was made, with good IOP response (14 mmHg).

\section{Clinical case 4}

A 71-year-old female without antiplatelet or anticoagulant therapy diagnosed with POAG with moderate glaucomatous damage showed glaucoma progression and borderline IOP despite medical treatment (26 $\mathrm{mmHg}$ ), warranting a NPDS with 5-fluorouracil and phacoemulsification in the right eye. Intraocular pressure 24 hours after surgery was $26 \mathrm{mmHg}$, with blood in the scleral lake. We decided to observe the patient expecting that aqueous humor filtration would help to drain the hematoma. Subsequent examinations showed a decrease in the amount of blood in the scleral lake (Fig. 1), but IOP remained high $(24 \mathrm{mmHg})$ so topical hypotensive treatment was reinitiated and a goniopuncture was performed 2 months after surgery. After the procedure, IOP remained at $22 \mathrm{mmHg}$ so we restarted hypotensive treatment to control it $(15 \mathrm{mmHg})$. 


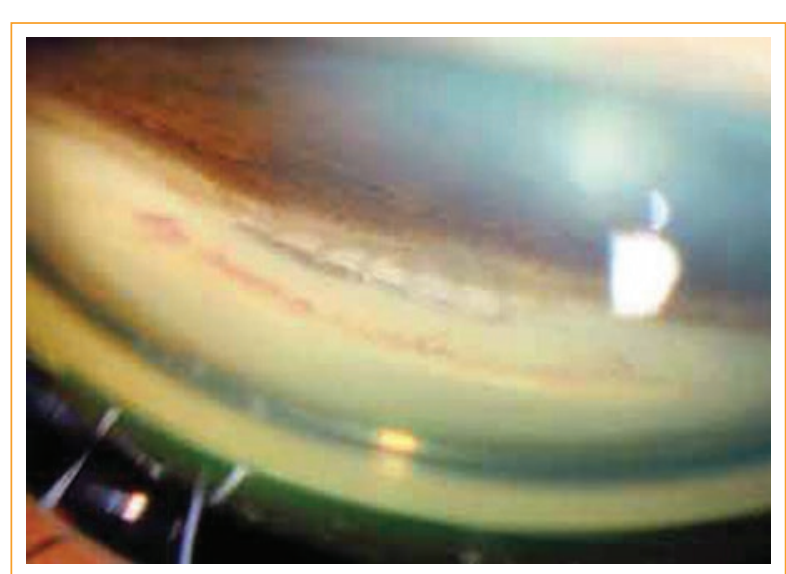

Figure 1. Scleral lake hematoma in resolution. Gonioscopy showing a clear trabeculo-Descemet's window with small blood remnants in the anterior area. The posterior area shows the edge of the Esnoper scleral implant through the membrane.

\section{Clinical case 5}

A 73-year-old female was treated with acetylsalicylic acid as antiaggregant therapy and had a diagnosis of POAG, with an IOP of $26 \mathrm{mmHg}$ and glaucoma progression despite hypotensive treatment, warranting NPDS with 5 -fluorouracil and phacoemulsification in the right eye. Intraocular pressure 24 hours after surgery was $23 \mathrm{mmHg}$, observing blood in the scleral lake, so topical treatment with timolol + brimonidine was started. A goniopuncture was performed one month after surgery, achieving subsequent IOP control (15 mmHg) without the need of topical hypotensive treatment.

\section{Discussion}

NPDS with concurrent antimetabolites has been shown to be effective in reducing $\mathrm{IOP}^{2,3}$ and has advantages over trabeculectomy, such as maintaining the structural integrity of the eye, avoiding sudden decompression and allowing an earlier return to everyday physical activities ${ }^{4}$. Also, it reduces complications due to hyperfiltration, since the trabeculo-Descemet's membrane provides a more controlled filtering system. However, it has some potential disadvantages, such as the need of antimetabolites to improve IOP results ${ }^{5}$, and it also requires periodic follow-up, since there may be a delayed increase in resistance to aqueous humor outflow ${ }^{6}$.

However, NPDS is not exempt from complications like trabeculo-Descemet's membrane rupture, postoperative ocular hypertension, bleb fibrosis, inability to identify Schlemm's canal and iris incarceration? ${ }^{7}$. Other common complications of trabeculectomy with a lower prevalence are choroidal detachment, prolonged hypotonia, hyphema, narrow anterior chamber and a positive Seidel test ${ }^{4}$.

In our case series we present another complication, which is the presence of a hematoma in the scleral lake. This complication has not been widely described in the literature, nor it has been reported that it adversely affects IOP control $^{8}$. In our opinion, the presence of the hematoma may cause malfunctioning of the procedure, hindering the adequate flow of the aqueous humor through the scleral lake; also, the presence of blood can induce early fibrosis of the flap, with subsequent IOP increase after surgery.

The main treatment for our patients was goniopuncture, which facilitates blood drainage to the anterior chamber and increases aqueous humor outflow; this helps to eliminate blood remnants in the scleral lake and to establish an adequate outflow. Once the scleral lake flow has been restored, if the IOP remains elevated, a bleb examination may eliminate external fibrosis. Both anterior segment OCT and anterior ultrasound biomicroscopy are valuable diagnostic tests, provided they are available, as they demonstrate the presence or absence of a scleral bleb and lake, and whether the examination with a needle may be useful or not ${ }^{9,10}$.

In the five patients of our series, the hematoma appeared in the first 15 days after surgery, was diagnosed by gonioscopy and in all cases caused an IOP increase. Although total or partial reabsorption of the hematoma was observed in subsequent examinations, IOP remained elevated. In all patients a goniopuncture was performed at different time-points after the intervention, and in two of them a needle examination of the filtering bleb with mitomycin- $C$ was also performed with the aim to open the walls of the bleb and lift the superficial flap if it was accessible. Even with this procedure, target IOP was achieved only in two cases, and in the remaining three cases it was necessary to reinitiate hypotensive treatment.

We conclude by highlighting the importance of scleral lake hematomas as a cause for NPDS failure, which warrants an early diagnosis and an aggressive treatment to avoid external fibrosis. Nevertheless, due to the few number of cases reported, we cannot conclude if goniopuncture and/or cystotomy with mitomycin-C injection are effective to successfully treat this complication.

\section{Ethical disclosures}

Protection of human and animal subjects. The authors declare that no experiments were performed on humans or animals for this study. 
Confidentiality of data. The authors declare that they have followed the protocols of their work center on the publication of patient data.

Right to privacy and informed consent. The authors declare that no patient data appear in this article.

\section{Funding}

The authors received no specific funding for this work.

\section{Conflicts of interest}

The authors declare no conflicts of interest.

\section{References}

1. Ramos López FJ, Francés Muñoz E, López-Sánchez EV, et al. Estimación de la eficacia de la esclerectomía profunda no perforante en el tratamiento quirúrgico del glaucoma al ãno de la cirugía. Arch Soc Esp Oftalmol. 2003;78:197-201.

2. Lachkar $Y$, Hamard $P$. Nonpenetrating filtering surgery. Curr Opin Ophthalmol. 2002;13:110-5.

3. Marek R, Joanna W, Lewczuk K, et al. Efficacy and safety of deep sclerectomy and phacoemulsification and deep sclerectomy in clinical of Military Health Service Institute-yearly observations. Klin Oczna. 2006;108:385-91.

4. Vazi RT, Silvai PC, Colombini GN. Goniosynechiae as a complication of non-penetrating deep sclerectomy by inappropriate use of mydriatic: Case report. Arq Bras Oftalmol. 2008;71:599-600.

5. Shin $\mathrm{DH}$, Iskander NG, Ahee JA, et al. Long-term filtration and visual field outcomes after primary glaucoma triple procedure with and without mitomycin-C. Ophthalmology. 2002;109:1607-11.

6. Muñoz-Negrete FJ, Rebolleda G, Noval S. Facoesclerectomía profunda no perforante. Resultados y complicaciones. Arch Soc Esp Oftalmol. 2003;78:499-506.

7. Roy S, Mermoud A. Complications of deep nonpenetrating sclerectomy. J Fr Ophtalmol. 2006:29:1180-97.

8. Gemma Rebolleda G, Muñoz FJ. Complicaciones de cirugías combinadas: facoemulsificación + trabeculectomía o esclerectomía profunda no perforante. En: Lorente R, Mendicute J, editores. Cirugía del cristalino. Madrid: MAC LINE SL.; 2008. p.1263-73.

9. Bouhéraoua N1, Hamard P, Iordanidou V, et al. Assessment of anterior segment anatomy by OCT after non penetrating deep sclerectomy. J Fr Ophtalmol. 2012;35:760-7.

10. Osman EA. The benefit of ultrasound biomicroscopy (UBM) in management of total Descemet's membrane detachment after deep sclerectomy surgery. Int Ophthalmol. 2011;31:345-8. 